Grażyna B. Szczygiet

\title{
THE THREAT OF TERRORISM PERCEIVED BY POLISH SOCIETY*
}

I. Violence and terror are as old as the human race. Terrorism is a type of violence which, as B. Hołyst has noted ${ }^{1}$, is a fairly new and has "developed" in the contemporary world. In his opinion, what contributed to the expansion of terrorism was technological progress and growth of the mass media. "After all, what the perpetrators of such acts want most of all is to gain publicity" and to instill fear in a large number of people. The terrorist attacks in New York City, Bali, Madrid, and London, confirm the words of Ban Ki-Moon ${ }^{2}$ who said that terrorism affects "all nations - large and small, rich and poor. Its victims are people of all ages, incomes, cultures, and religions."

Although no terrorist attacks have taken place in Poland, the mass media have made us realize how tragic the events in New York City, Madrid, London, and Egypt were. Has this caused Poles to be concerned that Poland, too, may one day become the target of terrorist attacks?

In an effort to answer this question, I will present the results of public opinion surveys performed by the Public Opinion Center (CBOS). CBOS has conducted public opinion polls for many years, and lately one of its research topics has been terrorism. The research was conducted on a representative sample of Polish citizens, selected randomly in conformance to the principles of randomization which assure that the sample fully represents the Polish society with regards to gender, age, education level, place or residence, and region.

II. The first time terrorism was an object of public opinion research was in September 2001, immediately after the terrorist attacks on the twin towers of the World Trade Centre in New York City. At that time over half (51\%) of the survey

\footnotetext{
Article was done in 2009.

B. Hołyst, Terroryzm [Terrorism], volume 1, Warsaw 2009, 47.

http://www.unic.un.org.pl/terroryzm/działania_sekr.php/
} 
participants expressed their concern that Poland may become the target of terrorist attacks.

Table no. 1 Do you believe that Poland may become the target of terrorist attacks?

\begin{tabular}{|c|c|c|c|c|c|c|}
\hline $\begin{array}{c}\text { Can Poland become } \\
\text { the target of terrorist } \\
\text { attacks? }\end{array}$ & \multicolumn{7}{|c|}{ Responses, by date of survey (in \%) } \\
\cline { 2 - 7 } & SEP 2001 & OCT 2001 & DEC 2001 & JAN 2002 & JUN 2002 & JUN 2003 \\
\hline Probably so & 51 & 52 & 54 & 49 & 45 & 53 \\
\hline Probably not & 37 & 38 & 37 & 41 & 44 & 38 \\
\hline It's hard to tell & 12 & 10 & 10 & 10 & 11 & 9 \\
\hline
\end{tabular}

Source: Data from CBOS research reports mentioned in the bibliography.

Over one third (37\%) of survey participants did not share this concern. A fairly small group (only 12\%) of respondents did not have an opinion on this issue. A month later, the number of persons who believed that Poland could become the target of terrorist attacks was a little larger (one percentage point) compared to September 2001. Interestingly, in October 2001 the governments of the United States and the United Kingdom decided to launch military operations in Afghanistan against Osama bin Laden's Al-Qaeda and the Taliban regime which supported it. These operations did not make a significant impact on the opinion of Poles' regarding the threat of terrorism. In December 2001, the percentage of respondents who thought that Poland could become a target of terrorist attacks increased by 2 percentage points.

The survey conducted in January 2002, showed a decrease in the respondents' sense of being threatened. The percentage of respondents who thought that Poland could become the target of terrorist attacks dropped by 5 percentage points compared with that in December 2001. The trend continued in June 2002. Compared to September 2001, the percentage of survey participants who believed that Poland could become the target of terrorist attacks decreased from $51 \%$ to $45 \%$. The survey conducted in June 2003 showed a growing concern about terrorism among Poles. Over a half of the survey participants believed that Poland could be attacked by terrorists. The increase could be explained by the fact that prior to the survey it was publically announced that, starting on 1 September 2003, Polish troops would administer one of the stabilization zones in Iraq. 
The Threat of Terrorism...

Table no. 2 Do you agree with the opinion that, due to the presence of Polish soldiers in Iraq, Poland may become a target of terrorist attacks by Islamic fundamentalists?

\begin{tabular}{|c|c|c|c|c|c|c|c|c|c|c|}
\hline Do you agree with the & \multicolumn{10}{|c|}{ Responses, by date of survey (in \%) } \\
\cline { 2 - 16 } $\begin{array}{c}\text { opinion that Poland may } \\
\text { become a target of terrorist } \\
\text { attacks? }\end{array}$ & $\begin{array}{c}\text { JUL } \\
2003\end{array}$ & $\begin{array}{c}\text { SEP } \\
2003\end{array}$ & NOV & DEC & MAR & MAY & JUL & SEP & OCT & AUG \\
\hline I agree & 66 & 58 & 75 & 71 & 87 & 86 & 83 & 83 & 82 & 83 \\
\hline I disagree & 23 & 33 & 18 & 21 & 9 & 10 & 13 & 13 & 13 & 13 \\
\hline I do not know & 8 & 9 & 6 & 8 & 4 & 4 & 4 & 4 & 5 & 104 \\
\hline
\end{tabular}

Source: Data from CBOS research reports mentioned in the bibliography.

As previously announced, between June and August 2003, the Polish Army deployed troops to the Middle East in order to fulfill its 1 September commitment. This situation could have made an impact on the concerns among Poles. The survey conducted in July 2003 showed that $66 \%$ of respondents agreed with the opinion that, due to the presence of Polish soldiers in Iraq, Poland may become the target of terrorist attacks by Islamic fundamentalists. However, this data may be considered as questionable, due to the fact that very different results were obtained in the September 2003 survey, when the Polish forces began their administration of the stabilization zone in Iraq. The percentage of respondents who agreed with the statement that Poland could become the target of terrorist attacks dropped by 4 percentage points and the percentage of respondents who thought otherwise increased by 6 percentage points. However, in November the former value significantly increased, by 7 percentage points, compared to that in September 2003. In December 2003, the percentage of persons who agreed with the statement amounted to nearly $3 / 4(71 \%)$ of all respondents.

The next survey was conducted in March 2004. That was the month of the most bloody terrorist attack perpetrated by Al-Qaeda in Europe. The bombing in the Madrid subway left 200 people dead and 1,400 wounded in its wake. This event did make an impact on public opinion in Poland with regards to the likelihood of terrorist attacks in our country. A large majority of participants (over $3 / 4$, or $87 \%$ ) believed that Poland could become the target of terrorist attacks. It should be noted that September 2004, was the month of the tragic events in Beslan, where the death toll was 339, including 159 children. Such a large increase in the percentage of concerned persons (approximately 83\%) remained unchanged in the following months, indeed until July 2005. In July 2005, terrorist attacks paralyzed the British capital city. In the London attacks 52 people were killed and 700 - wounded. Also, in July 2005, terrorists perpetrated a series of bombings in the Egyptian resort 
Sharm El Sheikh. The attacks resulted in the death of at least 70 people and left 150 wounded.

The next survey was conducted in November 2007, when Polish soldiers participated in military operations in Afghanistan.

Table no. 3 Are you concerned that the participation

of Polish soldiers in military operations in Afghanistan may lead

to terrorist attacks by Islamic fundamentalists in Poland?

\begin{tabular}{|c|c|c|c|}
\hline \multirow{2}{*}{$\begin{array}{c}\text { Are you concerned that the participation of Polish soldiers in } \\
\text { military operations in Afghanistan may lead to terrorist attacks by } \\
\text { Islamic fundamentalists in Poland? }\end{array}$} & \multicolumn{3}{|c|}{ Responses, by date of survey } \\
\cline { 2 - 4 } & $\begin{array}{c}\text { NOV } \\
2007\end{array}$ & APR 2008 & SEP 2008 \\
\hline I am concerned & 65 & 57 & 60 \\
\hline I am not concerned & 27 & 33 & 33 \\
\hline It's hard to tell & 8 & 10 & 7 \\
\hline
\end{tabular}

Source: Data from CBOS research reports mentioned in the bibliography.

The percentage of respondents who declared that they were concerned that this may provoke terrorists to attack Poland was $63 \%$. The results of the survey conducted in June and September of the following year indicate that in June the percentage of respondents who were concerned that the participation of Polish soldiers in military operations in Afghanistan may lead to terrorist attacks by Islamic fundamentalists in Poland, dropped by 7 percentage points, but as early as September the percentage of such respondents reached $60 \%$.

Another survey was conducted during talks regarding the installation of elements of the American missile defense system in Poland. In that survey, respondents were asked about their opinions regarding the impact of such a system on the likelihood of terrorist attacks in Poland.

Table no. 4 Do you believe that construction of an American military base constituting a part of the missile defense system will increase the risk of attacks by Islamic fundamentalists in Poland or that it will not increase this risk?

\begin{tabular}{|c|c|c|c|c|}
\hline Do you believe that construction of an American & \multicolumn{4}{|c|}{ Responses, by date of survey (in \%) } \\
\cline { 4 - 6 } $\begin{array}{c}\text { military base constituting a part of the missile defense } \\
\text { system will increase the risk of attacks by Islamic } \\
\text { fundamentalists in Poland or that it will not increase } \\
\text { this risk? }\end{array}$ & $\begin{array}{c}\text { FEB } \\
2008\end{array}$ & $\begin{array}{c}\text { APR } \\
2008\end{array}$ & $\begin{array}{c}\text { SEP } \\
2008\end{array}$ & $\begin{array}{c}\text { DEC } \\
2008\end{array}$ \\
\hline It will increase the risk. & 56 & 56 & 53 & 54 \\
\hline It will not increase the risk. & 29 & 31 & 33 & 35 \\
\hline It's hard to tell & 15 & 13 & 14 & 11 \\
\hline
\end{tabular}

Source: Data from CBOS research reports mentioned in the bibliography. 
The survey conducted in February 2008 indicates that most respondents (56\%) believed that an American military base constituting a part of the missile defense system would increase the risk of attacks by Islamic fundamentalists in Poland. More than 1 in 4 respondents (29\%) did not believe so. In the following months, the percentage of people who thought that elements of the missile defense system installed in Poland would increase the risk of terrorist attacks decreased, but not significantly: only by 2-3 percentage points. No significant changes in the opinions of survey participants were recorded in August 2008, when the Polish government and the United States government signed an agreement concerning the location of anti-ballistic missiles in Poland. What is notable is that the surveys conducted in April, September, and December 2008 showed a growth, compared to the results of the February 2008 survey, in the percentage of persons who thought that installation of elements of the missile defense system in Poland would not increase the risk of terrorist attacks in Poland. Such persons constituted $31 \%-35 \%$ of all the respondents, whereas in February 2008 the number was $29 \%$. This increase was the result of the drop (from $15 \%$ to $11 \%$ ) of the number of people who declared that they were unable to assess the threat.

III. The surveys also included questions concerning the respondents' personal sense of being threatened.

Table no. 5 Are you concerned about terrorist attacks at all?

\begin{tabular}{|c|c|c|c|c|c|c|c|c|}
\hline \multirow{2}{*}{$\begin{array}{c}\text { Are you concerned about terrorist } \\
\text { attacks at all? }\end{array}$} & \multicolumn{7}{|c|}{ Responses, by date of survey (in \%) } \\
\cline { 2 - 10 } & NOV & $\begin{array}{c}\text { DEC } \\
2001\end{array}$ & $\begin{array}{c}\text { JUN } \\
2001\end{array}$ & $\begin{array}{c}\text { DEC } \\
2002\end{array}$ & $\begin{array}{c}\text { MAR } \\
2003\end{array}$ & $\begin{array}{c}\text { APR } \\
2004\end{array}$ & $\begin{array}{c}\text { AUG } \\
2004\end{array}$ & $\begin{array}{c}\text { SEP } \\
2005\end{array}$ \\
\hline Yes, very concerned & 12 & 11 & 11 & 15 & 29 & 22 & 18 & 17 \\
\hline Yes, rather concerned & 27 & 28 & 27 & 37 & 35 & 39 & 38 & 48 \\
\hline I am concerned & 39 & 39 & 38 & 52 & 64 & 61 & 56 & 65 \\
\hline No, rather not concerned & 38 & 36 & 37 & 30 & 24 & 27 & 29 & 7 \\
\hline I am not concerned at all & 22 & 21 & 20 & 10 & 10 & 11 & 13 & 20 \\
\hline I am not concerned & 60 & 57 & 57 & 40 & 34 & 38 & 42 & 27 \\
\hline It's hard to tell & 2 & 4 & 5 & 8 & 2 & 1 & 2 & 8 \\
\hline
\end{tabular}

Source: Data from CBOS research reports mentioned in the bibliography.

The responses indicate that in November 2001, over 1 in 3 respondents (39\%) declared that they were concerned about terrorist attacks. The sense of being threatened personally was on the same level at the end of 2001 and in June 2002 it had increased by 1 percentage point. It should be noted that at that time over a half 
of all respondents believed that Poland could become the target of terrorist attacks. Thus, one can conclude that a certain group thought that they would not be affected by terrorist acts. This may be caused by the fact that the terrorist attacks perpetrated in the United States focused on selected targets.

A significant increase in personal concerns was noted in the survey conducted in December 2003. At that time over a half (52\%) of respondents declared that they were personally concerned about becoming a victim of a terrorist attack or that a member of their family could become one. When considering this data, one must remember that at that time Polish soldiers were involved in military operations in the Middle East. A large increase in the personal sense of being threatened was recorded in March 2004. The percentage of persons who declared that they were personally concerned about terrorist attacks grew by $12 \%$ compared to December 2003. This significant increase of personal concern can be linked to the Madrid bombing which took place in March. There are two possible explanations for this result. Firstly, at that time Spanish soldiers were involved in operations in the Middle East and terrorists ha issued several warnings that they would strike countries that send their troops to the region. Thus, the bombing was a fulfillment of these warnings. Secondly, one must also consider the impact of the location of the bombing on the personal fears of the respondents. The bombing took place in the subway, which is a place where anyone could go, as opposed to places accessible to only small groups of people, such as office buildings.

In August 2005, the percentage of persons who were personally concerned about terrorist attacks decreased by 5\% compared to April 2004. In the next survey, which was conducted in September 2007, 65\% of respondents declared their personal concern.

IV. The definition of a threat is of particular importance in surveys where respondents are asked about their opinions regarding the presence of the threat. In the case of terrorism there are problems with defining it. It should be noted that B. Hołyst, who is an expert in this field, in his two-volume book titled "Terrorism" says that "so far it has been impossible to elaborate universally binding or unanimously accepted definitions of 'terror' and 'terrorism"" and that "one should be aware of the fact that there are over one hundred different definitions of terror and terrorism and

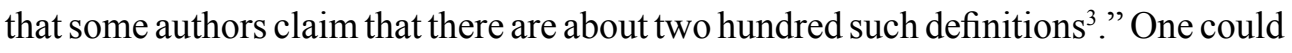
expect that the persons who conducted the surveys presented several definitions to avoid related problems. When asked the question "What is contemporary terrorism," respondents could pick from among the following definitions: an effort to intimidate and to raise fear, a means to acquire a lot of money and power, a contemporary 
The Threat of Terrorism...

method of fighting opponents, and a method of bringing attention to one's needs and problems.

Table no. 6 In general, what in your opinion is contemporary terrorism?

$\begin{array}{|c|c|c|c|}\hline \multirow{2}{*}{\begin{array}{c}\text { In general, what in your opinion is contemporary } \\ \text { terrorism? }\end{array}} & \multicolumn{3}{|c|}{\text { Responses, by date of survey (in \%) }} \\$\cline { 2 - 4 } & \text {$\left.OCT 2001 } & \text { APR 2004 } & \text { AUG 2005 } \\ \hline \text { An effort to intimidate and to raise fear } & 42 & 52 & 51 \\ \hline \text { A means to acquire a lot of money and power } & 25 & 16 & 19 \\ \hline \text { A method of fighting opponents } & 14 & 13 & 13 \\ \hline \text { A method of bringing attention to one's needs and } \\ \text { problems }\end{array}\right)$

Source: Data from CBOS research reports mentioned in the bibliography.

The largest group of respondents identified terrorism as an effort to intimidate and to raise fear. In the research conducted in October 2001, which was after the terrorist attacks on the World Trade Center in New York, nearly half (42\%) of all respondents selected this definition and one in four indicated that terrorism is a means to acquire a lot of money and power. In the survey conducted in April 2004, which was after the tragic terrorist attack in Madrid, the percentage of respondents who believed that terrorism was an effort to intimidate and to raise fear grew significantly, by 10 percentage points. Equally significant ( 9 percentage points) was the reduction of the number of people who thought that contemporary terrorism was a means to acquire a lot of money and power. The results of the surveys conducted in August 2005, after the terrorist attacks in London and Egypt, were similar.

The cause of terrorism that the respondents identified most often was religious fanaticism. Over half of respondents indicated this cause.

Table no. 7 What in your opinion is the most important cause of terrorism?

\begin{tabular}{|c|c|c|}
\hline \multirow{2}{*}{ What in your opinion is the most important cause of terrorism? } & \multicolumn{2}{|c|}{ Responses, by date of survey (in \%) } \\
\cline { 2 - 3 } & OCT 2001 & AUG 2005 \\
\hline religious fanaticism & 50 & 52 \\
\hline poverty & 13 & 13 \\
\hline political fanaticism & 10 & 7 \\
\hline lack of possibility to satisfy one's demands & 11 & 6 \\
\hline lack of freedom and independence & 5 & 5 \\
\hline sense of helplessness and powerlessness & 6 & 4 \\
\hline defense of traditional values and lifestyle & & 3 \\
\hline different customs and culture & & 2 \\
\hline others & 4 & 1 \\
\hline it's hard to tell & 1 & 7 \\
\hline
\end{tabular}

Source: Data from CBOS research reports mentioned in the bibliography. 
Only a minority (13\%) indicated poverty, lack of possibility to satisfy one's demands, and religions fanaticism as the causes of terrorism.

VI. Considering the fact that many countries, including Poland, have implemented a number of measures aimed at preventing terrorist attacks and that such measures may become an obstruction in human lives and even interfere with citizens' rights and freedoms, there is a question of whether citizens are willing to accept such measures.

Table no. 8 In exchange for a better sense of security, would you consider as just:

\begin{tabular}{|c|c|c|c|}
\hline \multirow{2}{*}{$\begin{array}{l}\text { In exchange for a better sense of security, } \\
\text { would you consider as just: }\end{array}$} & \multicolumn{3}{|c|}{ Responses, by date of survey (in \%) } \\
\hline & OCT 2001 & APR 2004 & AUG 2005 \\
\hline $\begin{array}{c}\text { intensified checks at national borders, airports, and train } \\
\text { stations }\end{array}$ & 95 & 94 & 95 \\
\hline bearing the cost of security systems & 71 & 50 & 56 \\
\hline tapping of telephone lines & 48 & 30 & 44 \\
\hline control of mail and e-mail & 42 & 26 & 46 \\
\hline $\begin{array}{l}\text { search of homes of persons suspected of contacts with } \\
\text { terrorists }\end{array}$ & & & 91 \\
\hline placing fingerprints in personal identity cards and passports & & & 81 \\
\hline monitoring the sales of simple chemicals & & & 79 \\
\hline implementation of more rigid immigration laws & & & 79 \\
\hline $\begin{array}{l}\text { mandatory collection of genetic material (DNA) of persons } \\
\text { suspected of terrorist activity }\end{array}$ & & & 78 \\
\hline search of luggage of public transportation passengers & & & 75 \\
\hline $\begin{array}{l}\text { shooting at suspects without warning and with the purpose of } \\
\text { killing }\end{array}$ & & & 24 \\
\hline
\end{tabular}

Source: Data from CBOS research reports mentioned in the bibliography.

In the survey conducted in October 2001, respondents were asked about four measures that could help fight terrorism, namely: intensified checks at national borders, airports, and train stations, bearing the cost of security systems, tapping of telephone lines, and control of mail and e-mail. A large percentage of respondents (95\%) declared that they considered as justified intensified checks at national borders, airports, and train stations, which are possible places of arrival of terrorists into Poland or places that may become targets of terrorist attacks due to the large number of people there. One should note that in the survey conducted in June 2004 and August 2005, equally large groups of respondents considered such measures to be justified actions aimed at increasing the sense of security. Thus, the respondents accepted some inconveniences caused by the more thorough checks. They were less willing to bear the cost of security systems and efforts. Less than 3 out of 4 respondents $(71 \%)$ declared that they were willing to bear such costs. Remarkably, 
this group greatly decreased in the subsequent surveys. In the survey conducted in April 2004, only 50\% of respondents declared such willingness, and in August 2005 $-56 \%$.

Another remarkable fact is that respondents were much less willing to accept measures that interfere with their freedom. In the survey conducted in October 2001, tapping telephone lines and controlling mail and email was acceptable to only $48 \%$ and $42 \%$ of respondents, respectively. In the subsequent research the percentages went down significantly: by 18 percentage points in the case of tapping telephone lines and by 16 percentage points in the case of controlling mail and email. In the research conducted in August 2005, the percentage of persons approving such measures was similar to that in October 2001.

The survey conducted in August 2005 included a greatly expanded list of measures aimed at increasing the sense of security. The distribution of data in table 8 shows that the most widely accepted measure was intensified checks at border crossings, airports, and train stations. This measure was accepted by nearly all respondents (95\%). An equally large group of respondents (91\%) accepted search of homes of persons suspected of contacts with terrorists. More than 3 out of 4 respondents (81\%) approved of placing fingerprints on personal identity cards and passports. The measures that the respondents thought would not affect them directly, such as monitoring the sales of simple chemicals, implementing more rigid immigration laws, and mandatory collection of genetic material (DNA) from persons suspected of terrorist activities, were widely accepted (78-79\%). A large group of respondents $(75 \%)$ approved of search of luggage of public transportation passengers. Notably, fewer than 1 in 4 respondents (24\%) approved of shooting at suspects without warning with the purpose of killing.

$\mathrm{V}$. The sense of being threatened by terrorism has remained high in Poland since the attack on the World Trade Center in New York City on 11 September 2001.

Diagram no. 1 The sense of being threatened by terrorism

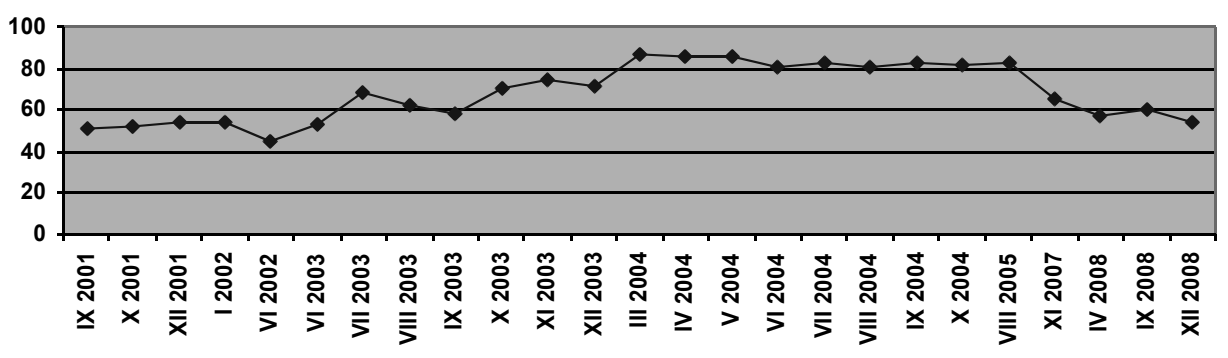

Data from CBOS research reports mentioned in the bibliography. 
In the years 2001-2003, a large number of respondents (51\%-71\%) were concerned that Poland could become the target of terrorist attacks. The fears grew after the bombings in Madrid and London. At that time, over $80 \%$ of respondents believed that events similar to those that had happened in Spain and United Kingdom could take place in Poland. In the ensuing years, no events took place that could fuel the respondents' sense of being threatened and the level of concern about terrorist attacks remained constant.

The survey conducted as a part of the research project titled "Monitoring, identifying, and countering threats to public security" shows that currently respondents believe that the level of terrorist threat is low. Only $27 \%$ of respondents declared that they were concerned about terrorist attacks. 


\section{ZAGROŻENIE TERRORYZMEM W OPINII POLSKIEGO SPOKECZEŃSTWA}

Wprawdzie w Polsce nie miały miejsca zamachy terrorystyczne, lecz środki masowego przekazu uwidoczniły nam tragizm wydarzeń w Nowym Jorku, Madrycie, Londynie czy Egipcie. Czy zrodziły się obawy, iż pewnego dnia nasz kraj również może stać się obiektem działań terrorystów? Podejmując próbę odpowiedzi, wykorzystano wyniki badań opinii publicznej prowadzonych przez Centrum Badania Opinii Publicznej (dalej jako CBOS). Instytucja ta od wielu lat zajmuje się badaniami opinii społecznej, a w ostatnich latach wśród problemów badawczych pojawiło się także zagrożenie terroryzmem. Cezura czasowa to lata, w których miały miejsce zamachy terrorystyczne w wyżej wymienionych obszarach.

Key words:

Violence, terror, terrorist attack, public opinion, personal sense of being threatened 